African Journal of Business and Economic Research (AJBER)

(Online) ISSN 1750-4562 (Print) ISSN 1750-4554

Indexed by SCOPUS, UGC CARE List, IBSS, EBSCO, ProQuest, ABDC, SAJE, COPERNICUS, CABELL, Sabinet and J-Gate

Vol. 16, (Issue 1), March 2021

pp $143-162$

\title{
Socio-economic Factors Affecting Household
}

Participation in

Curb-Side Recycling Programmes: Evidence from Drakenstein Municipality, South Africa

DOI: https://doi.org/10.31920/1750-4562/2021/v16n1a6

\section{Liza Volschenk}

School of Economics and Econometrics,

University of Johannesburg,

Johannesburg, South Africa.

Email: lizav@uj.ac.za

Orcid number: 0000-0002-5150-7560

\section{Kotie Viljoen}

School of Economics and Econometrics,

University of Johannesburg,

Jobannesburg, South Africa.

Email:kotiev@uj.ac.za

Orcid number:0000-0001-6087-9684

Corresponding author

$\&$

Catherina Schenck

DSI/NRF/CSIR Chair in W aste and Society,

University of the Western Cape, Bellville,

Cape Town, South Africa

Email: cschenck@uwc.ac.za

Orcid number:0000-0001-5299-5355 


\section{Abstract}

Household curb-side recycling programmes have the potential to reduce waste that end up in landfills. However, participation in these programmes is low. The aim of this study is to investigate the socioeconomic factors that impact households' participation in the curb-side recycling (CSR) programme in one municipality. Based on a convenience sample, quantitative data were collected from 247 households using a structured questionnaire. The data were analysed with a binary Probit regression model. The findings suggest that the education levels of household member(s) responsible for household waste management activities, length of time households have lived in their dwelling, size of the household, access to free recycling bags, presence of school-going children in the household, and sufficient information on the CSR programme and process had a statistically significant positive impact on participation. Knowledge of these factors can assist policy makers in identifying ways to encourage household participation and, in so doing, contribute to more efficient CSR programmes.

\section{Introduction}

Access to waste services and service levels differ greatly across geographic areas and municipalities (StatsSA, 2017). Only around 63.9\% of all households in South Africa had access to domestic waste collection services in 2016 (StatsSA, 2017), with more regular waste collection services in the more affluent and urban suburbs (DEA, 2012; Hall, 2010). Waste services in urban informal, tribal and rural formal areas are still lacking due to a historical backlog (DEA, 2012). The number of South African households that participate in recycling initiatives are therefore low; for the total household population ranges between $7.2 \%$ in urban areas and 2.6\% in rural areas (Strydom \& Godfrey, 2016). The low level of participation is a cause for concern as more waste is produced globally than ever before due to an increase in consumption and a "throw away" culture (Oelofse \& Godfrey, 2008). South Africa produces 55,000 tonnes of waste daily (two kilograms per capita per day) and is ranked the 15th highest waste producer globally (DEFF, 2020; Business Tech, 2017). Scientists globally are questioning whether the earth can sustain the current rate of environmental degradation due to the acceleration of waste generation (Idoko, Nkamnebe \& Amobi, 2013). 
Many municipalities in South Africa are facing landfill space shortages, with some municipalities having less than 10 years of remaining landfill space (Anyasi \& Atagana, 2017). This has encouraged municipalities to find innovative solutions to landfilling in line with the National Environmental Management Waste Act 59 of 2008 (NEMWA) (Strydom \& Godfrey, 2016). The National Waste Management Strategy (NWMS) (DEA, 2011) in 2011 set goals to minimise waste that require changes in the management of solid waste. One goal required municipalities to initiate curb-side recycling (CSR) programmes at household level in all major cities and towns by 2016, which was not achieved (Strydom \& Godfrey, 2016). CSR refers to the separation of household waste in recyclables and non-recyclables for collection, whereafter the recyclables are recycled by recycling companies to produce new products (Ho, 2002; Miller, 2006). In 2018, only about $11 \%$ of all waste in South Africa was recycled and diverted from the landfills (DEFF, 2020).

International studies that focused on household waste management include those in Japan (Matsumoto, 2011), Malaysia (Akil, Foziah \& Ho, 2015), India (Jayasubramanian, Meenakshi Saratha \& Divya, 2015), the United States of America (USA) (Jakus, Tiller \& Park, 1996) and Uganda (Ekere, Mugisha \& Drake, 2009). Ekere et al. (2009) found that peer influence, gender of household member involved in recycling and the location of a household to have a significant effect on the recycling behaviour of households in the Lake Victoria crescent of Uganda. Jakus et al. (1996; 1997) found that storage, space and time-cost influenced participation rates in the USA. They further indicated that older people are more likely to recycle than younger people and recyclers had higher incomes than non-recyclers. Matsumoto (2011) found no relationship between recycling behaviour and age in Japanese municipalities. The success of CSR programmes depends on '.. the active and sustained involvement of people’ (Ittiravivongs, 2011:437).

Studies report different results for different regions, which justify area-specific studies. In developing countries, solid waste policies should be more focused on environmental sustainability (Best, Struwig \& Muthwa, 2019) and finding solutions to the unique problems faced by specific municipalities. An area-specific assessment of the recycling challenges faced by people in the same demographic area is necessary (Lehman \& Geller, 2004). The area-specific focus motivated the study in Drakenstein Municipality in the Western Cape Province of South Africa. The aim of this study is to understand the socio-economic factors that 
influence participation of households in the CSR programme in the municipality. Identifying factors that affect household participation in CSR are key to understanding people's recycling behaviours and habits (Strydom \& Godfrey, 2016; Oyekale, 2018) and identifying policies to increase participation.

\section{Literature review}

The behaviour of households is complex and participation in recycling initiatives are influenced by many socio-economic factors. This section reports on the empirical results of previous studies that identified socioeconomic factors that might influence household participation in recycling activities and initiatives.

Demographic factors play a role in recycling behaviour. Evidence on the relationship between gender and recycling behaviour is mixed. Females in the USA tend to participate more in recycling activities than males (Saphores, Nixon, Ogunseitan \& Shapiro, 2006). However, Gamba and Oskamp (1994), Werner and Makela (1998) and Meneses and Palacio (2005) found that this is not necessarily the case.

Previous studies also found mixed results in the relationship between age and recycling participation. Vining and Ebreo (1990), Jakus et al. (1996; 1997), Meneses and Palacio (2005) and Saphores et al. (2006) found that older people in households in the USA were more likely to recycle than younger people and the likelihood of recycling by a household increased by 1.6 times when at least one individual in the household is a retiree (Nixon \& Saphores, 2009).

A positive relationship between education levels and recycling involvement was found in studies by Jakus et al. (1996), Saphores et al. (2006) and Ekere et al. (2009). In Malaysia, the majority of people responsible for the household recycling had at least a secondary school education (Akil \& Ho, 2014). Other studies found no statistically significant relationship between recycling behaviour and education levels (Gamba \& Oskamp, 1994; Meneses \& Palacio, 2005; Nixon \& Saphores, 2009).

The presence of school-going children in the household plays a role in recycling behaviour. A comparative study between Sweden and Singapore emphasised the importance of instilling environmentally conscious behaviour in children from an early age to have a long-term effect on their pro-environmental attitudes and behaviours as adults (Ho, 2002). A study from the United Kingdom (UK) suggests that, while 
educating the youth is important for pro-environmental behaviour, part of the solution lies in also educating the rest of the household (Maddox, Doran, Williams \& Kus, 2011).

Household income and consumption also influence recycling participation and Vining and Ebreo (1990), Shultz, Oskamp and Mainkieri (1995), Jakus et al. (1996), Saphores et al. (2006) and Ekere et al. (2009) found a statistically significant positive relationship between recycling participation and income in the USA, suggesting that recyclers generally have higher incomes than non-recyclers.

Household characteristics, including the number of years a household has stayed in their house, has positively affected recycling participation in Thailand (Ittiravivongs, 2011) and Ethiopia (Tadesse, Ruijs \& Hagos, 2008) although the results were not statistically significant in Ethiopia.

The size of a household also seems to influence a household's participation in CSR as Nixon and Saphores (2009) found larger households are more likely to participate in waste separation. Likewise, in Uganda, Ekere et al. (2009) reported a statistically significant relationship between the size of the household and recycling participation showing that for every additional household member, the probability of waste separation increased by $19 \%$.

Facilities and resources provided play a role in recycling. In Malaysia, recycling habits were found to be poor due to the lack of recycling facilities and resources (Omran, Mahmood, Abdul Aziz \& Robinson, 2009). Research in large metropolitan areas of South Africa found that respondents were more likely to recycle if the recyclables were collected at their curb-side and less likely to recycle the further away collection points are from their homes (Strydom, 2018).

A study on the impact of social media by Ho, Liao and Rosenthal (2015) in Singapore found that media dependency and media attention on waste management positively contributed to pro-environmental behaviour. Environmental authorities use the mass media to start campaigns aimed at raising awareness and motivating environmentally responsible behaviour. When individuals watched relevant information on national television, it had a positive effect on their pro-environmental behaviour (Lowrey, 2004; Ho et al., 2015).

Knowledge is key to determining recycling behaviour and increased recycling knowledge translates into changes in recycling behaviour (Akil \& Ho, 2014; Vining \& Ebreo, 1990). People should be made aware of the impact of improper waste management (Jayasubramanian et al. 2015). A lack of knowledge is also seen as a contributing factor to the low CSR 
participation rates of households in South Africa (Strydom, 2018). Individuals who are more aware of the consequences of their actions are more likely to engage in pro-environmental programmes like CSR (Barr, Ford \& Gilg, 2003).

These identified socio-economic factors were used to guide this study in identifying factors that Drakenstein Municipality can use to design policies to benefit its waste management strategies at the household level.

\section{Research methods}

A cross-sectional research design and a quantitative research methodology were used for the study. Cross-sectional studies are conducted to estimate the prevalence of the outcome of interest in a target population and provide a "snapshot" of characteristics associated with the outcome at a particular point in time (Levin, 2006). The target population is households in Drakenstein Municipality situated in suburbs where a CSR programme is in place.

\section{Sample size}

Municipal officials managing the CSR programme in Drakenstein pointed out six suburbs where a CSR programme is in place. The population size in these suburbs is 1880 households according to an official at the municipality (2019, personal communication, 31 May). The 247 questionnaires that were completed are justified as representative of the population at a margin of error of $5 \%$ and a confidence interval of 90\% (Qualtrics, 2020). During the data cleaning process, seven of these questionnaires could not be used.

\section{Sampling method}

This study used a convenience sampling technique, which is a nonprobability sampling method (Etikan, Musa \& Alkassim, 2016). The sample size includes households that were willing and available to participate at the time of the fieldwork. Respondents had to be older than 18 years and representative of their household to ensure the validity of the information. A random sampling technique could not be used due to challenges of people that were too busy and/or not home and people not wanting to open their doors to the fieldworkers. The convenience 
sampling helped to gather data from more households than what would have been possible with a probability sampling technique. Although a non-probability sampling technique has its limitations for generalisations, it is a good tool to use when randomisation is not possible (Etikan et al., 2016).

\section{Data collection tool and procedure}

Primary data were collected from households with a structured questionnaire. The questionnaire is a modified questionnaire created by Viljoen (2014) for a previous study. The modifications were informed by the literature review and validated by experts. The questionnaire covered questions on the demographics of the participants and their household, general household characteristics, waste management in the household, the households' participation in the CSR programme, the use of social media, reasons for non-participation in the CSR programme and ways in which the municipality can encourage and motivate households to participate in the CSR programme.

To improve the accuracy of the information gathered, the fieldworkers were trained by one of the researchers before conducting the interviews. Ethical clearance and official permission from the municipality and the relevant university were obtained and adhered to in the study.

\section{Data analysis}

The data was captured in Excel and analysed in STATA. The descriptive analysis included frequencies, means and medians. The Probit model tested the extent to which each of the explanatory variables (socioeconomic factors) impact the probability of the households' participation in the CSR programme, as well as the significance thereof.

The Probit regression model is expressed in the following equation:

$\mathrm{p} i=\beta_{0}+\beta_{1} X_{1}+\beta_{2} X_{2}+\beta_{3} X_{3}+\ldots+\beta_{n} X_{n}+\mathrm{U} i$

The dependent variable ( $\mathrm{i} i$ ) represents the probability (Gujarati, 2003) of households' participation in the CSR programme. The dependent variable has two possible outcomes (binary variable) (Greene, 1996), with a value of $1(\mathrm{p} i=1)$ if the household participates in the CSR programme and $0(\mathrm{p} i=0)$ otherwise. 
$\beta 0=$ constant term

$\beta 1$ to $\beta \mathrm{n}=$ coefficients to be estimated

$X_{1}$ to $X_{n}=$ socio-economic factors (explanatory variables) and

$\mathrm{U} i=$ error term

This paper also reports the marginal effects that take the partial change in the probability into account.

The explanatory variables include gender, age, education, income, months living in the same dwelling, household size, access to CSR bags, use of social media, school-going children in the household and sufficient information available on CSR.

The explanatory variables in the Probit model account for $66 \%$ of the variation in CSR participation. The Probit model was tested for multicollinearity through the Variance Inflation Factor (VIF). The mean VIF of 1.43 indicates that there is no multicollinearity present in the model (Gujarati, 2003). To test for goodness-of-fit, the Hosmer and Lemeshow test was used. Robust standard errors were included to control for heteroscedasticity (Gujarati, 2003). The results of the descriptive analyses and Probit regression models are discussed next.

\section{Results and discussion}

The results are reported as descriptive and Probit model results.

\section{Demographic characteristics}

The suburbs in Drakenstein where CSR has been implemented are the more urbanised and predominantly White and Afrikaans-speaking suburbs. Most $(95 \%)$ of these households reside in a house and have lived in these dwellings for 16 years on average. The size of the households ranged from very small (one member) to large households (ten members) with an average of three members.

\section{Characteristics of household member(s) responsible for waste management}

Table 1 lists the characteristics of household member(s) responsible for waste management activities (WMA). WMA generally refers to separating the waste or simply putting mixed waste on the curb for municipal collection. 
Table 1: Characteristics of household member(s) responsible for waste management

\begin{tabular}{|c|c|c|c|c|c|}
\hline \multirow[b]{2}{*}{ Variables } & & \multicolumn{2}{|c|}{ Participants } & \multicolumn{2}{|c|}{ Non-participants } \\
\hline & & $\mathrm{n}$ & $\%$ & $\mathrm{n}$ & $\%$ \\
\hline \multirow{4}{*}{$\begin{array}{l}\text { Gender } \\
(n=229)\end{array}$} & Male & 31 & 20.0 & 36 & 48.7 \\
\hline & Female & 69 & 44.5 & 26 & 35.1 \\
\hline & Male and female & 55 & 35.5 & 12 & 16.2 \\
\hline & Total & 155 & 100.0 & 74 & 100.0 \\
\hline \multirow{7}{*}{$\begin{array}{l}\text { Age } \\
(n=220)\end{array}$} & $15-24$ & 3 & 2.0 & 4 & 5.8 \\
\hline & $25-34$ & 9 & 6.0 & 11 & 15.9 \\
\hline & $35-44$ & 17 & 11.3 & 15 & 21.7 \\
\hline & $45-54$ & 35 & 23.2 & 19 & 27.5 \\
\hline & $55-64$ & 36 & 23.8 & 12 & 17.4 \\
\hline & $65+$ (Retirement age) & 51 & 33.8 & 8 & 11.6 \\
\hline & Total & 151 & 100.0 & 69 & 100.0 \\
\hline \multirow{5}{*}{$\begin{array}{l}\text { Education } \\
(\mathrm{n}=197)\end{array}$} & Some secondary & 3 & 2.2 & 7 & 11.3 \\
\hline & Secondary completed & 37 & 27.4 & 29 & 46.8 \\
\hline & Certificate/diploma & 26 & 19.3 & 10 & 16.1 \\
\hline & Tertiary education & 69 & 51.1 & 16 & 25.8 \\
\hline & Total & 135 & 100.0 & 62 & 100.0 \\
\hline
\end{tabular}

\begin{tabular}{ll|llllll}
\hline Variable & & $\mathbf{n}$ & Mean & Median & SD & Min & Max \\
\hline $\begin{array}{l}\text { Age } \\
(\mathrm{n}=220)\end{array}$ & Participants & 151 & 57.34305 & 58.0 & 14.9513 & 20 & 92.0 \\
& Non-participants & 69 & 47.23913 & 47.5 & 15.3157 & 15 & 82.5 \\
\hline
\end{tabular}

Source: Survey Data (2019)

Female(s) were responsible for WMA in 41.4\% households, whereas, in $29.3 \%$ households, both a male and female were responsible for WMA. The high female WMA responsibility rate might be explained by the fact that females are generally the homemakers and caretakers who oversee the day-to-day running of household activities (Oates \& McDonald, 2006). The majority (44.5\%) of the households that participate in CSR are also those where a female was responsible for the WMA.

The average age of household members responsible for WMA in the CSR-participating households was 57 years, opposed to an average age of 47 for CSR non-participating households. Household members 
responsible for WMA, in the 65 years and older category had the highest CSR participation rate $(33.7 \%)$ while those in the 15 to 24 age category had the lowest CSR participation rate $(2 \%)$. The age category with the highest CSR non-participation rate $(27.5 \%)$ was the 45 to 54 age category. These results are similar to those by Akil and Ho (2014) and Nixon and Saphores (2009), who found that the presence of older people in the household increases the probability of household CSR participation.

The results further highlight that CSR participating household members responsible for WMA had higher levels of education than the CSR non-participating households. Most members of CSR-participating households' members responsible for the WMA (51.1\%) have tertiary level education while most members of non-participating households $(46.8 \%)$ only completed their secondary school education. These results agree with those of Jakus et al. (1996), Saphores et al. (2006) and Ekere et al. (2009), who found evidence to suggest a positive relationship between education levels and recycling involvement.

Table 2 shows the gross monthly income categories of households that participate in CSR and those that do not.

Table 2: $\quad$ Gross monthly income categories for households $(n=184)$

\begin{tabular}{l|ll|lc}
\hline & \multicolumn{2}{|l|}{ Participants } & \multicolumn{2}{|c}{ Non-participants } \\
Income categories & $\mathrm{n}$ & $\%$ & $\mathrm{n}$ & $\%$ \\
\hline R0-R6 400 & 7 & 5.9 & 15 & 23.1 \\
R6 401-R12 800 & 20 & 16.8 & 11 & 16.9 \\
R12 801-R25 600 & 40 & 33.6 & 11 & 16.9 \\
R25 601-R51 200 & 25 & 21.0 & 17 & 26.2 \\
R51 201+ & 27 & 22.7 & 11 & 16.9 \\
\hline Total & 119 & 100.0 & 65 & 100.0 \\
\hline Source: Surver
\end{tabular}

Source: Survey Data (2019)

Of the 155 CSR-participating households, the largest percentage (33.6\%) earned between R12,801 and R25,600 per month compared to only $16.9 \%$ of CSR non-participating households. A further $22.6 \%$ of CSRparticipating households earned R51,201 and more per month compared to $16.9 \%$ CSR non-participating households. In the lowest income category (below R6,400 per month), the CSR-participating households were fewer $(5.8 \%)$ than the CSR non-participating households $(23 \%)$. These results suggest a positive relationship between income and CSR 
participation and follow a similar pattern to those of Jakus et al. (1996) and Saphores et al. (2006) who found that recyclers tend to have higher incomes than non-recyclers. One explanation for these results might be that the higher the household income is, the more recyclable waste the household generates (Ekere et al., 2009).

\section{Availability of facilities and resources}

Access to free CSR bags provided by the municipality seems to play an important role in the decision to participate in the CSR programme, as illustrated in Figure 1. More than 80\% CSR-participating households received free CSR bags weekly, whereas only between $27 \%$ and $33.4 \%$ non-participating households received free CSR bags from the municipality.

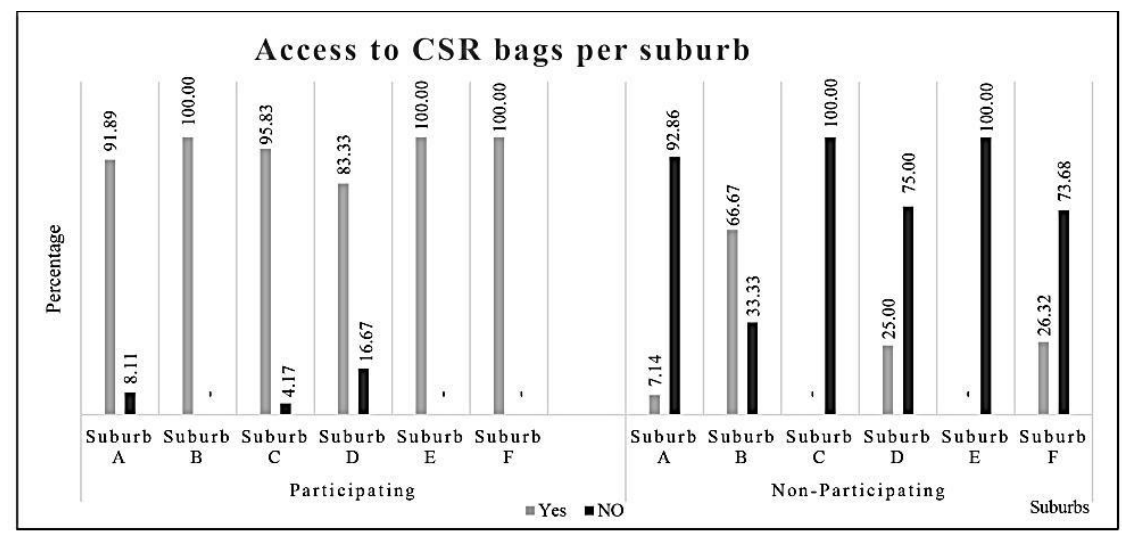

Source: Survey Data (2019)

Figure 1: Access to free curb-side recycling bags $(n=219)$

The results suggest that some households do not get free bags for recycling, which negatively affects households' participation in the CSR initiative. The reasons might be that the bags got stolen or were simply not delivered or replaced by the municipality. The negative effect is similar to findings in Malaysia where the lack of recycling resources is associated with poor recycling habits (Omran et al., 2009). 


\section{Results of the Probit regression model}

The results of the Probit model in Table 3 show that where females were responsible for the WMA in a household, the probability of household participation in CSR increased by $10 \%$ more than cases in which only males were responsible for household waste management activities. These results are, however, not statistically significant, like the findings of Gamba and Oskamp (1994), Werner and Makela (1998) and Meneses and Palacio (2005). Moreover, Shultz et al. (1995) found that gender is not a good predictor of recycling in the USA as different studies in different regions have opposing results.

Table 3: Results of the Probit model

\begin{tabular}{|c|c|c|c|}
\hline CSR participation status & Coeff. & SD & Marginal effects \\
\hline Constant & -11.542 & 2.333 & \\
\hline \multicolumn{4}{|l|}{ Gender } \\
\hline Female & 0.9206114 & 0.5838708 & 0.100731 \\
\hline Male and Female & 0.3153694 & 0.5897111 & 0.038114 \\
\hline \multicolumn{4}{|l|}{ Age } \\
\hline $25-34$ & -0.6004078 & 0.9577335 & -0.06979 \\
\hline $35-44$ & -0.9079789 & 1.090894 & -0.10837 \\
\hline $45-54$ & -0.3289755 & 0.8577982 & -0.03732 \\
\hline $55-64$ & 1.467459 & 0.7634756 & 0.135008 \\
\hline $65+($ Retirement age $)$ & 1.012945 & 0.8899187 & 0.099451 \\
\hline \multicolumn{4}{|l|}{ Education } \\
\hline Secondary completed & $2.582342^{* *}$ & 0.8505658 & $0.343288^{* *}$ \\
\hline Certificate/Diploma & $3.164709^{* *}$ & 0.9283879 & $0.4186561 * * *$ \\
\hline Tertiary & $3.822816^{* *}$ & 1.080079 & $0.4911378^{* * *}$ \\
\hline \multicolumn{4}{|l|}{ Income } \\
\hline R6 401-R12 800 & $2.496788^{* *}$ & 1.006914 & $0.274895^{* * *}$ \\
\hline R12 801-R25 600 & $3.767503^{* *}$ & 1.174305 & $0.3552263^{* *}$ \\
\hline R25 601-R51 200 & 1.628391 & 1.005155 & 0.202083 \\
\hline R51 201+ & 1.02491 & 0.9508766 & 0.138881 \\
\hline Months in dwelling & $0.0050098^{* *}$ & 0.0020781 & $0.0005491^{* *}$ \\
\hline Household size & $0.5517678^{*}$ & 0.2176314 & $0.0604744 * *$ \\
\hline Access to CSR bag & $3.853082^{* * *}$ & 0.6959805 & $0.4223025^{* * *}$ \\
\hline Social media & 0.5878637 & 0.4302542 & 0.064431 \\
\hline School-going children & $1.490444 * * *$ & 0.6833891 & $0.1633545^{* *}$ \\
\hline Sufficient information & $1.193642 *$ & 0.4984061 & $0.130824^{*}$ \\
\hline Observations & 128 & & \\
\hline Prob $>c h i^{2}$ & 0.0000 & & \\
\hline Pseudo R2 & 0.6609 & & \\
\hline Hosmer-Lemeshow $c h i^{2}$ & 1.67 & & \\
\hline Prob $>c h i^{2}$ & 0.9894 & & \\
\hline Mean VIF & 1.43 & & \\
\hline
\end{tabular}

Dependent variable $=$ Household participation in CSR $(1=$ participation in CSR, $0=$ nonparticipation in CSR) Statistical significance: $0.01^{* * *}, 0.05^{* *}$ and $0.10^{*}$ 
The results for the age categories of the household member(s) responsible for WMA shows that the probability of a household participating in CSR only increases in the higher age categories (55-64 and $65+$ ) by $13.5 \%$ and $1 \%$, respectively. Although not statistically significant, these results are similar to those by Nixon and Saphores (2009), who found that having a retiree in the house was a predictor of positive recycling behaviour in the USA. This highlights the notion that older people might be more conscious about the world they leave behind for their children and grandchildren or they might have more time to separate the waste.

The results on the education level of the household member(s) responsible for WMA and CSR participation in the households show that the higher the educational category obtained by the household member(s) responsible for household WMA, the higher the probability of that household to participate in CSR. These results are statistically significant and are different from those of Gamba and Oskamp (1994), Meneses and Palacio (2005) and Nixon and Saphores (2009) who found no statistically significant relationship between recycling behaviour and education levels.

The probability of CSR participation is also higher for all income categories higher than R6,401. The probability of CSR participation increases more for households earning a gross monthly income in the $\mathrm{R} 6,401$ to R12,800 and R12,801 to R25,600 income categories. The higher probability to participate is also only statistically significant for these two categories. Therefore, there is no conclusive evidence that recyclers have a higher income than non-recyclers, thus contradicting the results reported by Jakus et al. (1997) and Saphores et al. (2006) in the USA who found that recyclers generally have a higher income than nonrecyclers.

The results for the number of months that households have lived in their current dwelling show a small but statistically significant increase $(p<0.05)$ of household CSR-participation. Overall, this variable shows that for every additional month lived in the dwelling, the probability of household CSR participation increases. This result might indicate that households who are settled are more familiar with the waste removal processes in the suburb, which might increase their probability of CSR participation.

For every additional family member in the household, the probability of household CSR participation increases by $6 \%$ and the result is statistically significant $(\mathrm{p}<0.05)$. Possibly, larger households have 
more people that can help separate the waste and encourage one another to keep on separating the waste. This result is in line with findings by Nixon and Saphores (2009), who found that the more individuals living in the household, the more likely they are to participate in waste separation. Ekere et al. (2009) also found this relationship to be statistically significant and reported an increase of 19\% for each additional household member.

The results further indicate how important access to free CSR bags for households is for increased household participation in CSR. The probability of households' CSR participation increases by $42.2 \%$ for households that receive their free CSR bags weekly. The results are statistically significant $(\mathrm{p}<0.01)$ and confirms the results by Omran et al. (2009) that a lack of resources is a driver for poor recycling habits and lower participation rates in Malaysia.

The use of social media increases the probability of households' CSR participation by $6.4 \%$. These results are similar to those of Ho et al. (2015) on media dependency and media attention in Singapore but is not statistically significant.

The presence of school-going children in the household increased the probability of participation in CSR of households by $16.3 \%$ and is statistically significant $(\mathrm{p}<0.05)$. This result confirms that part of the solution in waste management lies in educating the youth to educate the rest of the household, as advocated by Maddox et al. (2011). The results agree with the idea that when school children learn about waste management and pro-environmental behaviour at school, it has a spillover effect on households.

The importance of sufficient information on the CSR programme and its processes was highlighted as a positive contributor to the decision of households to participate in the CSR programme. If households have sufficient information available, the probability of CSR participation increases by $13.1 \%$ and is statistically significant at a $10 \%$ level. Ho (2002) explains that even if a person has a pro-environmental attitude or belief but lacks information, it will result in ineffective recycling behaviour.

\section{Conclusion and recommendations}

The low participation of households in municipal recycling initiatives is a concern for municipalities given the scarcity of available landfill space. 
The challenge is to find ways to increase household participation in CSR programmes.

The results of this study suggest that providing all households with sufficient and ongoing information on the process to be followed and types of waste to separate for CSR collection might increase households' participation. To reach as many households as possible, the municipality should use a variety of communication platforms, such as WhatsApp, a local Facebook page, the local newspaper, pamphlets, SMS and emails. Another reminder can be a fridge magnet that lists all the products that should be put aside for the CSR bag. As females are responsible for the WMA in the majority of CSR participating households, workshops on the CSR programme can be initiated by the municipality for women in the suburbs where the CSR programme is in operation.

The results that households who have lived longer in their existing dwelling are more familiar with the waste removal processes in the suburb emphasise the need to make newcomers to an area aware of the municipality's CSR programme.

The positive spill-over effect on households' CSR participation when school-going children are present in the household indicates that the municipality can benefit from liaising with schools in the municipal district to teach the children about the local CSR programme. The schools can also be encouraged to start a recycling campaign that includes a mascot so that children can associate pro-environmental behaviour with something positive. It is important to educate the youth at an early age so that pro-environmental thinking becomes a habit, as they are the policymakers of the future. As Maddox et al. (2011) pointed out, educate school-going children to educate the rest of their households.

The municipality should ensure that all households receive free CSR bag(s) to start with and that their filled bags are replaced with empty ones to ensure the sustainability of their participation in the CSR initiative. Another solution is to provide each household with a marked CSR bin that might be costly in the short term but can save the municipality the costs of providing bags in the long term. The bins would provide more capacity for more recyclable goods and are more aesthetically pleasing than the CSR bags. This might allow the municipality to collect the recyclable bins once every two weeks, saving on collection costs. However, this solution requires further investigation and a cost-benefit analysis. 
Although the results of the study are area-specific, the recommendations can also be applied to similar municipalities and local authorities in South Africa.

\section{Limitations of the study and areas for further research}

The limitations of this study include the inability to use a random sampling technique as many household members were not home during the survey period, and some of those who were home were either too busy or did not want to participate in the study.

Future research can investigate the costs and benefits to the municipality of providing CSR bins instead of CSR bags. Further research may also investigate how CSR differ among municipalities in different provinces in South Africa.

\section{Acknowledgement}

The authors acknowledge funding support from the South African Department of Science and Innovation (DSI), the National Research Foundation (NRF) through the Waste RDI Roadmap, managed by the Council for Scientific and Industrial Research (CSIR).

\section{References}

Akil, A.M., Foziah, J., \& Ho, C.S. (2015), "The effects of socio-economic influences on households recycling behaviour in Iskandar Malaysia" Procedia-Social and Behavioral Sciences, Vol. 202 August pp: 124-134.

Akil, A.M., \& Ho, C.S. (2014), "Towards sustainable solid waste management: Investigating household participation in solid waste management" Earth and Environmental Science, Vol. 18 No. 1 pp: 1-6.

Anyasi, R.O., \& Atagana, H.I. (2017), "Assessing people's behavior towards recycling: A case of Upper Claremont South Africa" International Journal of Environmental \& Science Education, Vol. 12 No. 8 pp: 1751-1764.

Barr, S., Ford, N.J., \& Gilg, A.W. (2003), "Attitudes towards recycling household waste in Exeter, Devon: Quantitative and qualitative approaches" Local Environment, Vol. 8 No. 4 pp: 407-421. 
Best, L., Stuwig, M., \& Muthwa, S. (2019), African contemporary policy advances in sustainable consumer protection. African Journal of Business and Economic Research (AJBER), Vol. 14 No. 3 pp: 7-32.

Business Tech (2017), How much rubbish South Africans dump each day? Infrastructure News. Accessed 20 April 2019, from https://infrastructurenews.co.za/2016/08/17/how-much-rubbishsouth-africans-dump-each-day/

DEA (Department of Environmental Affairs) (2011), National Waste Management Strategy, (Pretoria, South Africa, Government Printers).

DEA (Department of Environmental Affairs) (2012), South African Environment Outlook: Waste Management - Chapter 13, (Pretoria, South Africa, Government Printers).

Department of Environment, Forestry and Fisheries (2020) National Waste Management Strategy, (Pretoria) South African Government Printers. https://amcham.co.za/wp- content/uploads/2020/09/

National-Waste-Management-Strategy-2020_13Sept2020.pdf

Ekere, W., Mugisha, J., \& Drake, L. (2009), "Factors influencing waste separation and utilization among households in the Lake Victoria crescent, Uganda" Waste Management, Vol. 29 No. 12 pp: 3047-3051.

Etikan, I., Musa, S.A., \& Alkassim, R.S. (2016), "Comparison of convenience sampling and purposive sampling" American Journal of Theoretical and Applied Statistics, Vol. 5 No. 1 pp: 1-4.

Gamba, R.J., \& Oskamp, S. (1994), "Factors influencing community residents' participation in commingled curbside recycling programs" Environment and Behavior, Vol. 26 No. 5 pp: 587-612.

Greene, W.H. (1996), "Marginal effects in the Binary Probit Model". Working paper No. EC-96-11, New York University.

Gujarati, D.N. (2003), Basic Econometrics, $4^{\text {th }}$ ed., (West Point: McGraw Hill United States Military Academy).

Hall, D. (2010) South Africa - Waste - Unequal services and outsourcing of waste management servicesPublic Services International Research Unit. Business School of the University of Greenwich, UK.

Ho, Y.Y. (2002), "Recycling as a sustainable waste management strategy for Singapore: An investigation to find ways to promote Singaporean's household waste recycling behaviour", Thesis (Lund, Sweden, Lund University).

Ho, S.S., Liao, Y., \& Rosenthal, S. (2015), "Applying the theory of planned behavior and media dependency theory: Predictors of public pro-environmental behavioral intentions in Singapore" Environmental Communication, Vol. 9 No. 1 pp: 77-99. 
Idoko, E.C., Nkamnebe, A.D., \& Amobi, D.S.C. (2013), "Public Policy and SMEs' adoption of environmental sustainability orientation in Enugu, Nigeria" African Journal of Business and Economic Research (AJBER), Vol. 8 No. 1 pp: 11-31.

Ittiravivongs, A. (2011), "Factors influence household solid waste recycling behaviour in Thailand: An integrated perspective" WIT Transactions on Ecology and the Environment, Vol. 167 No. 1 pp: 437-448.

Jakus, P.M., Tiller, K.H., \& Park, W.M. (1996), "Generation of recyclables by rural households" Journal of Agricultural and Resource Economics, Vol. 21 No. 1 pp: 96-108.

Jakus, P.M., Tiller, K.H., \& Park, W.M. (1997), "Explaining rural household participation in recycling" Journal of Agricultural and Applied Economics, Vol. 29 No. 1 pp: 141-148.

Jayasubramanian, P., Meenakshi Saratha, M., \& Divya, M. (2015), "Perception of households towards waste management and its recycling in Coimbatore" International Journal of Multidisciplinary Research and Development, Vol. 2 No. 1 pp: 510-515.

Lehman, P., \& Geller, E. (2004), "Behavior analysis and environmental protection: Accomplishments and potential for more" Behavior and Social Issues, Vol. 13 No. 1 pp: 13-32.

Levin, K.A. (2006), "Study design III: Cross-sectional studies” Evidencebased desntistry, Vol. 7 No. 1 pp:24-25.

Lowrey, W. (2004), "Media dependency during a large-scale social disruption: The case of September 11" Mass Communication and Society, Vol. 7 No. 3 pp: 339-357.

Maddox, P., Doran, C., Williams, I.D., \& Kus, M. (2011), “The role of intergenerational influence in waste education programmes: The THAW project” Waste Management, Vol. 31 No. 12 pp: 2509-2600.

Matsumoto, S. (2011), "Waste separation at home: Are Japanese municipal curbside recycling policies efficient?" Resources, Conservation and Recycling, Vol. 55 No. 3 pp: 325-334.

Meneses, G.D., \& Palacio, A.B. (2005), "Recycling behavior: A multidimensional approach" Environment and Behavior, Vol. 37 No. 6 pp: $837-860$.

Miller, R. G. (2006). "The ins and outs of curbside recycling programs". Science Scope, Vol. 30 No. 4 pp: 16-21.

Nixon, H., \& Saphores, J.D.M. (2009), "Information and the decision to recycle: Results from a survey of US households" Journal of Environmental Planning and Management, Vol. 52 No. 2 pp: 257-277. 
Oates, C.J., \& McDonald, S. (2006), "Recycling and the domestic division of labour: Is green pink or blue?" Sociology, Vol. 40 No. 3 pp: 417-433. Oelofse, S.H.H., \& Godfrey, L. (2008), "Defining waste in South Africa: Moving beyond the age of 'waste"' South African Journal of Science, Vol. 104 No. 7 pp: 242-246.

Omran, A., Mahmood, A., Abdul Aziz, H., \& Robinson, G.M. (2009), "Investigating household attitude toward recycling of solid waste in Malaysia: A case study" International Journal of Environmental Research, Vol. 3 No. 2 pp: 275-288.

Oyekale, A.S. (2018), "Determinants of households' involvement in waste separation and collection for recycling in South Africa" Science and Business Media Environmental Development Sustain, Vol. 20 No. 5 pp: 2343-2371.

Qualtrics (2020). Academic experience Sample Size Calculator. [Online]. Available from: https://www.qualtrics.com/blog/calculating-samplesize/

Saphores, J.D.M., Nixon, H., Ogunseitan, O.A., \& Shapiro, A.A. (2006), "Household willingness to recycle electronic waste: An application to California" Environment and Behavior, Vol. 38 No. 2 pp: 183-208.

Shultz, P.W., Oskamp, S., \& Mainkieri, T. (1995), "Who recycles and when? A review of personal and situational factors" Journal of Environmental Psychology, Vol. 15 No. 2 pp: 105-121.

StatsSA (2016). The state of basic service delivery in South Africa: In-depth analysis of the Community Survey 2016 data. Statistics South Africa, Pretoria, South Africa.

Strydom, W.F. (2018), "Applying the theory of planned behavior to recycling behavior in South Africa" Natural Resources and the Environment, Council for Scientific and Industrial Research, Vol. 3 No. 3 pp: 43-78.

Strydom, W.F., \& Godfrey, L.K. (2016), Household waste recycling behaviour in South Africa: Has there been progress in the last 5 years? Proceedings of the 23rd WasteCon Conference and Exhibition, 17-21 October 2016, Emperors Palace, Johannesburg.

Tadesse, T., Ruijs, A., \& Hagos, F. (2008), "Household waste disposal in Mekelle City, Northern Ethiopia" Waste Management, Vol. 28 No. 10 pp: 2003-2012.

Viljoen, J.M.M. (2014), Participation of poor communities in separation at source initiatives: Vrededorp, South Africa. Unpublished paper. Johannesburg, South Africa, School of Economics and Econometrics University of Johannesburg. 
Vining, J., \& Ebreo, A. (1990), "What makes a recycler? A comparison of recyclers and nonrecyclers" Environment and Behaviour, Vol. 22 No. 1 pp: 55-73.

Werner, C.M., \& Makela, E. (1998), "Motivations and behaviors that support recycling” Journal of Environmental Psychology, Vol. 18 No. 4 pp: 373-386. 